\title{
Insights for Managers from \\ Confucius to Gandhi
}


This page intentionally left blank 


\section{Insights for Managers from \\ Confucius to Gandhi}

Harold Bierman, Jr. Donald Schnedeker

Cornell University, USA

\section{WF World Scientific}




\section{Published by}

World Scientific Publishing Co. Pte. Ltd.

5 Toh Tuck Link, Singapore 596224

USA office: 27 Warren Street, Suite 401-402, Hackensack, NJ 07601

UK office: 57 Shelton Street, Covent Garden, London WC2H 9HE

\section{British Library Cataloguing-in-Publication Data}

A catalogue record for this book is available from the British Library.

\section{INSIGHTS FOR MANAGERS FROM CONFUCIUS TO GANDHI}

Copyright (C) 2012 by World Scientific Publishing Co. Pte. Ltd.

All rights reserved. This book, or parts thereof, may not be reproduced in any form or by any means, electronic or mechanical, including photocopying, recording or any information storage and retrieval system now known or to be invented, without written permission from the Publisher.

For photocopying of material in this volume, please pay a copying fee through the Copyright Clearance Center, Inc., 222 Rosewood Drive, Danvers, MA 01923, USA. In this case permission to photocopy is not required from the publisher.

ISBN-13 978-981-4365-08-6

ISBN-10 981-4365-08-4

Typeset by Stallion Press

Email: enquiries@stallionpress.com

Printed in Singapore. 


\section{Preface}

It is difficult to define the most meaningful type of readings for managers. While current topical literature is fun and useful, we have decided that sampling the classics is fruitful.

The authors and subjects range from Aristotle to Carnegie to Young. The writings are not always easy, but we think you will find them thought provoking.

Most of the writings are short extractions. The basic objective was to give more than quotations, but less than the complete writings of any of the authors. Even the great authors did not write consistently at one high level of relevance for a manager.

Several thoughtful people have asked about the theme of this book. The included papers have several reasons for being chosen. First are the papers with an important message for the business reader. The pieces written by Andrew Carnegie and Owen D. Young are good examples. Second are the papers that are not directly written for business people but are highly relevant. Aristotle and Whitehead's papers are examples. The third type of papers included are those that offer a lesson useful for all readers. O'Henry and Fred Schwed qualify on this dimension. The fourth type of extract is included because they are classic examples of applying the English language to make a point. Lincoln's Gettysburg Address and Calvin 
Coolidge's speeches are examples. Should they be left out because they do not apply to a firm's capital structure or capital budgeting decisions? No, they deserve to be read by people interested in business and life.

The readings are for managers and other interested persons. The thoughts are too universal to be restricted to one subset of humanity, but if we have been successful in selection and in editing, the choices are particularly relevant for managers. We offer two suggestions. Do not try speed reading this book. It is a difficult voyage but the passage is likely to be worthwhile. Secondly, if you find an author to be interesting, we suggest you expand your exposure and read a larger sample.

For biographical facts, the internet source Wikipedia, the free encyclopedia was invaluable, though we claim the right to all errors of fact.

Harold Bierman, Jr. The Nicholas H. Noyes Professor of Business Administration Cornell University and Donald Schnedeker Librarian Cornell University 


\title{
Acknowledgments
}

\begin{abstract}
Many people contributed to the creation of this book. A sampling follows. Hal's wife, Florence, read the entire manuscript and made numerous very useful suggestions. His assistant, Barb Drake, was invaluable and his two sons, Bruce and Jon, made several good suggestions that made the cut. Tai Wei Lim was a very patient and helpful editor. Jerry Hass, a long-time friend and colleague, was always available to offer assistance.
\end{abstract}

Joel Silbey, the President White Professor of History, Cornell University, made two great suggestions for inclusions. Can you guess which items he suggested?

Susan Kendrick helped us navigate through the library stacks.

Thank you all. 
This page intentionally left blank 


\section{Contents}

Preface

Acknowledgments

Chapter 1 Confucius 1

1. Wit and Wisdom 2

Chapter 2 Laozi (also Lao Tse, Lao Tu, 7 Lao-Tzu, Laotze)

1. The Evidence of Simplicity 8

Chapter 3 Aristotle 9

1. The Subject of Ethics is the Good for Man 10

Chapter 4 Murasaki Shikibu (Lady Murasaki) 13

1. The Tale of Genji — Chapter I - Kiritsubo 14

$\begin{array}{lll}\text { Chapter } 5 \text { Bernier } & 37\end{array}$

1. The Divided Horsecloth 37

$\begin{array}{lll}\text { Chapter } 6 & \text { Niccolo Machiavelli } & 47\end{array}$

1. Chapter XXII - Ministers 48

2. Chapter XXV — How Far Fortune Influences 49 the Things of this World, and How Far She May Be Resisted

Chapter 7 Francis Bacon 
2. Icarus and Scylla and Charybdis, or the Middle Way. Explained of Mediocrity in Natural and Moral Philosophy

Chapter 8 William Shakespeare

1. Hamlet, Act I. Sc. III

Chapter 9 Thomas Hobbes

1. Introduction

2. Chapter IX - Of the Several Subjects of Knowledge

3. Chapter X - On Power, Worth, Dignity, Honour, and Worthiness

Chapter 10 René Descartes

1. Discourse on the Method of Rightly Conducting the Reason and Seeking the Truth in the Sciences 1.1. Part I

1. A Discourse Upon the Origin and the Foundation of the Inequality Among Mankind

Chapter 12 Adam Smith

1. An Inquiry into the Nature and Causes of the Wealth of Nations Book I - Of the Causes of Improvement in the Productive Power of Labour and of the Order According to Which its Produce is Naturally Distributed Among the Different Ranks of the People. Chapter I - Of the Division of Labour

2. Chapter II - Of the Principle Which Gives Occasion to the Division of Labour 
3. Book II - Of the Nature, Accumulation, and Employment of Stock

3.1. Introduction

4. Chapter II - Of Restraints Upon the Importation from Foreign Countries of Such Goods as can be Produced at Home

Chapter 13 George Washington

1. Farewell Address

Chapter 14 John Adams

1. Independence

Chapter 15 Patrick Henry

1. An Appeal to Arms

2. Give Me Liberty, or Give Me Death

Chapter 16 Thomas Jefferson

1. Inaugural Address

Chapter 17 Thomas Paine

1. These are the Times That Try Men's Souls

Chapter 18 Ralph Waldo Emerson

1. Self-Reliance

2. Compensation

3. Power

Chapter 19 Abraham Lincoln

1. Lincoln at Gettysburg

Chapter 20 Karl Heinrich Marx

1. Chapter IV - Position of the Communists in Relation to the Various Existing Opposition Parties 
Chapter 21 Andrew Carnegie

1. Labor - The Upward March of Labor 154

2. The Final Relation Between Capital and Labor - Labor and Capital Partners

Chapter 22 Alfred Marshall

1. Chapter V - The Scope of Economics

2. Chapter VIII - Industrial Organization

Chapter 23 Russell Conwell

1. Acres of Diamonds

Chapter 24 Elbert Hubbard

1. Publisher's Preface 206

2. Apologia 208

3. A Message to Garcia

Chapter 25 Louis Brandeis

1. Industrial Democracy

2. Absolutism in Industry

Chapter 26 Thorstein Veblen

1. An Early Experiment in Trusts

Chapter 27 Alfred North Whitehead

1. On Foresight

2. Requisites for Social Progress

1. The Gift of the Magi

2. The Unknown Quantity

Chapter 29 George Santayana

1. The Last Puritan, A Memoir in the Form of a Novel — Epilogue 
Chapter 30 Irving Fisher

1. The Risk Element

Chapter 31 W.E.B. DuBois

1. The Black United States

Chapter 32 Mohandas Karamchand Gandhi

283 (Mahatma Gandhi)

1. The Birth of Satyagraha

Chapter 33 Calvin Coolidge

287

1. The Supports of Civilization

289

2. Thought, The Master of Things

296

3. The Press Under a Free Government

304

4. Government and Business

Chapter 34 Alfred E. Smith

331

1. Post-Election Radio Address

Chapter 35 Owen D. Young

1. General Electric Develops a Labor Policy 340

Chapter 36 William O. Douglas

1. Chapter I - The Forces of Disorder 351

1.1. Destructive forces in finance 352

1.2. The "Curse of Bigness" 355

2. Chapter V - Corporation Managements 358

Chapter 37 Arthur E. Nilsson

363

1. Making Securities Secure

364

Chapter 38 Fred Schwed, Jr.

1. Chapter VIII — Investment - Many 372 Questions and a Few Answers 